\author{
В.А. Васильев, Р.В. Басий, А.И. Кулиш, О.А. Бешуля
}

ГОО ВПО «Донецкий национальный медицинский университет имени М. Горького», Донецк

\title{
ВЗАИМОСВЯЗЬ МОРФОМЕТРИЧЕСКИХ ПАРАМЕТРОВ СЕЛЕЗЕНКИ И АНТРОПОМЕТРИЧЕСКИХ ПОКАЗАТЕЛЕЙ ЛИЦ ЖЕНСКОГО ПОЛА ПЕРВОГО ПЕРИОДА ЗРЕЛОГО ВОЗРАСТА В ДОНЕЦКОМ РЕГИОНЕ
}

Селезенка относится к периферическим органам кроветворения и иммуногенеза и выполняет ряд важнейших для организма человека функций, таких как элиминация старых и поврежденных эритроцитов и тромбоцитов, депонирование крови или отдельных ее элементов и их выброс в кровеносное русло в случае кровопотери, участие в иммунной защите организма, миелопоэзе. Этот орган также является индикатором большого числа патологических состояний, обусловленных как гематологическими заболеваниями, так и патологиями другого генеза [1]. Многие нарушения, происходящие в организме, возникают без клинических проявлений, что требует изучения дополнительных биохимических или морфометрических маркеров. Одним из таких маркеров является изменение нормальных размеров селезенки, отражающих ее функциональное состояние. Однако на сегодняшний день вопрос о нормальных размерах органа остается открытым и нерешенным.

Наиболее информативным для оценки размеров селезенки и ее структуры является метод ультразвукового исследования. Кроме того, эхография является широкодоступным, неинвазивным и безопасным методом, что позволяет использовать его для обследования широких масс населения.

Корректную оценку морфометрических параметров селезенки, полученных при ультразвуковом исследовании, необходимо осуществлять с учетом половозрастных, антропометрических и соматотипологических особенностей исследуемого [2, 3]. Поэтому определение нормальных параметров селезенки у лиц женского пола первого периода зрелого возраста Донецкого региона с учетом соматотипа представляется актуальным.

\section{ЦЕЛЬ РАБОТ Ы}

Определить морфометрический эталон нормы селезенки, установить взаимосвязь количе- ственных параметров органа и антропометрических показателей практически здоровых лиц женского пола первого периода зрелого возраста Донецкого региона.

\section{МАТЕРИАЛ И МЕТОДЫ}

Объект исследования: 60 условно здоровых женщин - сплошная выборка, обратившихся в кабинет УЗИ с 2019 по 2020 год по соответствующим критериям включения: возраст от 21 до 35 лет, не имеющие вредных привычек и не предъявляющие жалоб на состояние здоровья, без заболеваний и травм селезенки в анамнезе. На проведение эхографии и антропометрии было получено добровольное информированное согласие.

На первом этапе работы проводилось ультразвуковое обследование селезенки на базе Донецкого клинического территориального медицинского объединения Министерства здравоохранения Донецкой Народной Республики в отделении ультразвуковой диагностики Республиканского диагностического центра. Эхография выполнялась аппаратом Radmir одним оператором в B-режиме серой шкалы, конвексным датчиком в стандартных положениях при продольном сканировании. Определялись следующие морфометрические параметры: длина селезенки - расстояние между наиболее удаленными точками ее концов; ширина селезенки - расстояние между наиболее удаленными точками переднего и заднего краев; толщина селезенки расстояние между наиболее удаленными точками в области ворот на висцеральной поверхности и по диафрагмальному контуру [6]. Объем селезенки рассчитывался по формуле:

OC $=0,524 \times a \times b \times c$,

где a - длина селезенки, b - ширина селезенки, с - толщина селезенки [7].

(c) В.А. Васильев, Р.В. Басий, А.И. Кулиш, О.А. Бешуля, 2021 (C) Университетская Клиника, 2021 
Далее в лаборатории кафедры анатомии человека им. проф. Н.Д. Довгялло проводилась антропометрия обследуемых с целью последующего определения соматотипа. Антропометрические измерения выполнялись по общепринятой методике в утренние часы в специально оборудованном кабинете [4]. При обследовании использовали следующий инструментарий: деревянный станковый ростомер, сантиметровую ленту, калипер, весы. Соматотипирование проводили по методике Б.Х. Хит, Д.Л. Картера [5].

Полученные результаты обрабатывались в пакете прикладных программ Statistica 10.

Формат представления данных в тексте: $\mathrm{m} \pm \mathrm{sd}$, где $\mathrm{m}$ - среднее значение, a sd - среднее квадратичное отклонение (для переменных, которые подчиняются нормальному закону распределения); $\mathrm{Me} \pm \mathrm{sd}$, где Me - медиана, a sd среднее квадратичное отклонение (для переменных, которые не подчиняются нормальному закону распределения).

\section{РЕЗУЛЬТАТЫ И ОБСУЖДЕНИЕ}

Результаты соматотипирования обследуемых позволяют утверждать, что среди лиц женского пола первого периода зрелого возраста Донецкого региона преобладают эндо-мезоморфный и мезо-эндоморфный соматотипы (см. табл.).

Для дальнейшей статистической обработки данных использовались параметрические или непараметрические критерии в зависимости от того, соответствовали ли они нормальному закону распределения частот величин или были отличны от него. Для проверки гипотезы о законе распределения частот величин использовался критерий Шапиро-Уилка на уровне значимости $\mathrm{p}<0,05$.

Среднее значение показателя роста всех об-

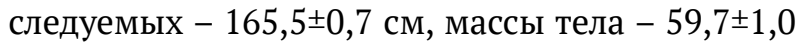
кг; среднее значение длины селезенки, полученное при ультразвуковом исследовании,

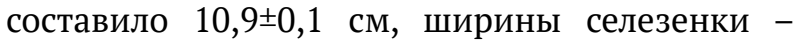
$5,8 \pm 0,1$ см. Медиана показателя толщины органа оказалась равна $4,7 \pm 0,1 \mathrm{~cm}$, объема селезенки $-154,8 \pm 5,4 \mathrm{CM}^{3}$.

У лиц эндо-мезоморфного типа телосложения получены следующие результаты антропометрии: среднее значение показателя роста обследуемых составило 164,6 1,0 см, массы тела $61,8 \pm 1,4$ кг. По данным эхографии, среднее значение длины селезенки - 10,9 $\pm 0,2$ см, ширины органа - 5,8 $\pm 0,1$ см. Медиана показателя шири-

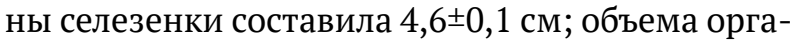
на $-152,7 \pm 8,6 \mathrm{~cm}^{3}$.

В группе лиц мезо-эндоморфного типа телосложения получены следующие результаты: среднее значение роста обследуемых - $169,1 \pm 1,2$ см, массы тела - 64,2 $\pm 1,3$ кг; среднее значение длины селезенки составило 11,3 $\pm 0,4$ см, ширины органа $-5,7 \pm 0,1$ см, толщины $-5,0 \pm 0,2$ см, объема селезенки - $170,0 \pm 10,8 \mathrm{~cm}^{3}$.

У лиц экто-мезоморфного типа телосложения получены следующие результаты: среднее значение показателя роста обследуемых составило $164,0 \pm 2,0$ см, массы тела - 51,9 $\pm 2,08$ кг, среднее значение толщины $-4,8 \pm 0,3$ см, объема - $161,9 \pm 12,8$ см$^{3}$. Медиана длины органа составила $11,5 \pm 0,4$ см, ширины $-5,7 \pm 0,1 \mathrm{~cm}$.

В выборке лиц эндо-эктоморфного типа телосложения получены следующие результаты: среднее значение роста - $163,3 \pm 2,7$ см, массы

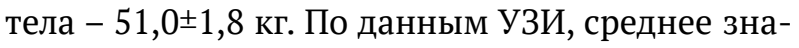
чение длины селезенки составило $11,0 \pm 0,3 \mathrm{~cm}$,

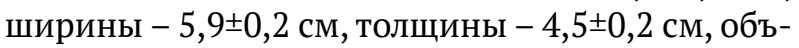
ема - $152,6 \pm 13,7 \mathrm{~cm}^{3}$.

На следующем этапе работы было определено наличие линейной корреляционной связи между величинами изучаемых показателей как независимо от соматотипа, так и у лиц наиболее часто встречающегося - эндо-мезоморфного соматотипа. В зависимости от того, подчинялось ли распределение частот величин показа-

Абсолютное число и удельный вес представителей различных соматоти-

Таблица. пов среди лиц женского пола первого периода зрелого возраста

\begin{tabular}{ccc}
\hline Количество человек, абс. & Удельный вес, $\%$ & Соматотип \\
\hline \hline 30 & 50 & эндо-мезоморфный \\
\hline 11 & 18 & мезо-эндоморфный \\
\hline 7 & 12 & экто-мезоморфный \\
\hline 7 & 12 & эндо-эктоморфный \\
\hline 2 & 3 & экто-эндоморфный \\
\hline 2 & 3 & эктоморфный \\
\hline 1 & 2 & мезо-эктоморфный
\end{tabular}




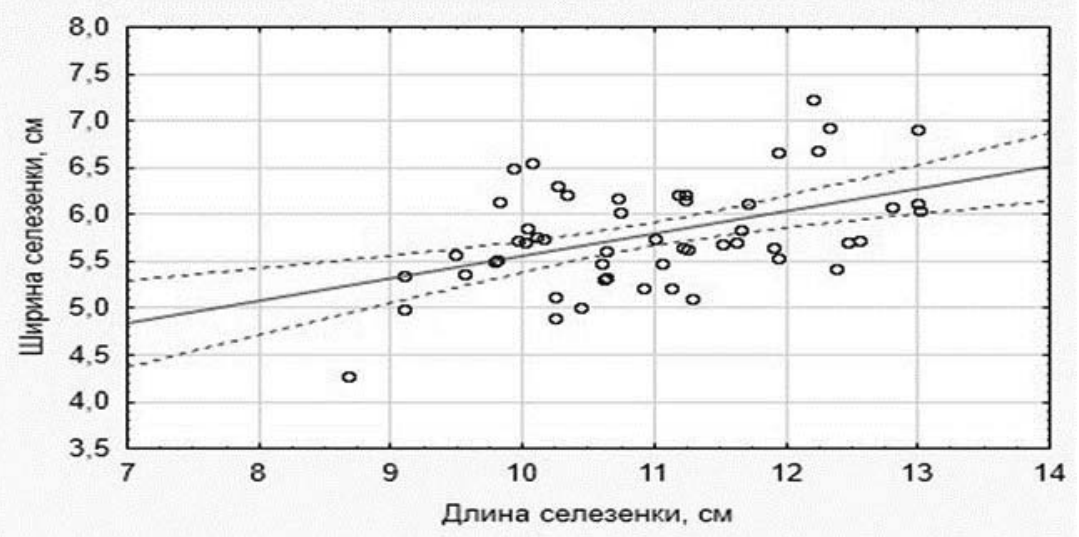

Рис. 1. График зависимости между величинами показателей длины и ширины селезенки по данным ультразвукового исследования

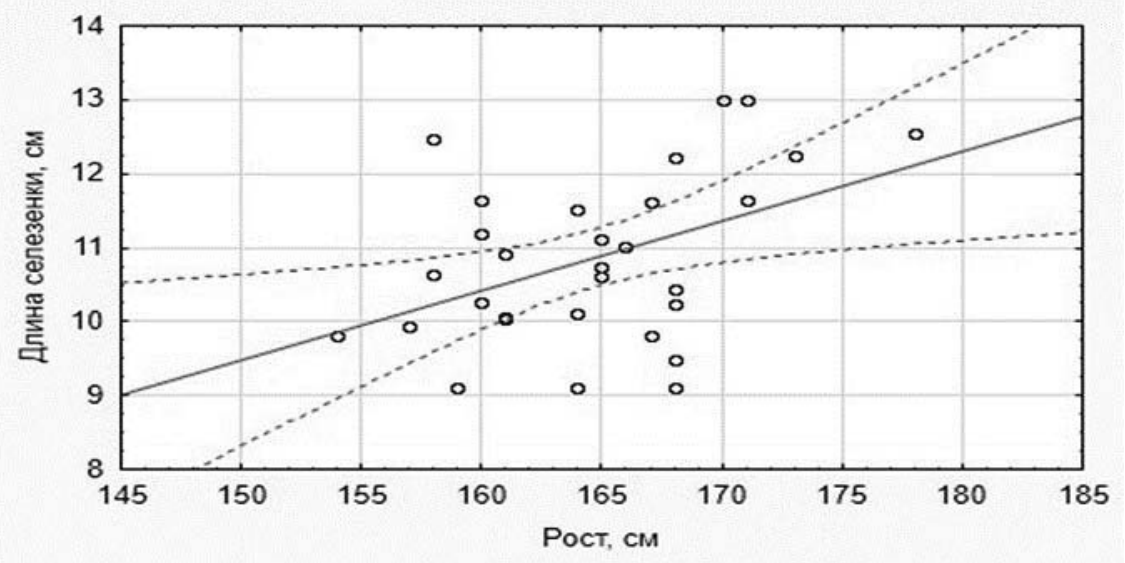

Рис. 2. График зависимости между ростом и длиной селезенки

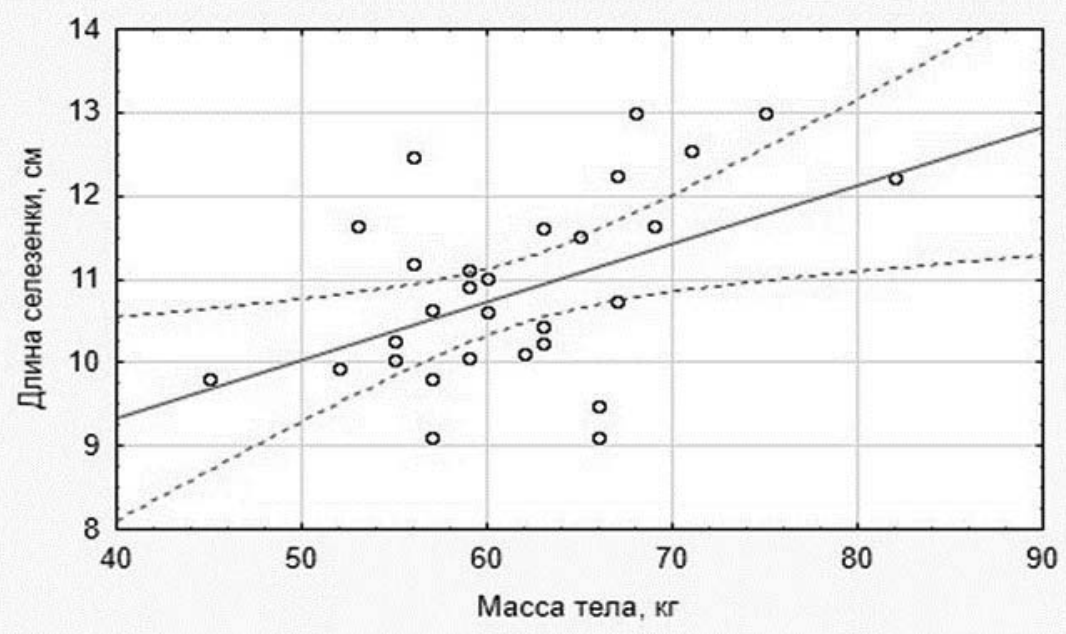

Рис. 3. График зависимости между массой тела и длиной селезенки 


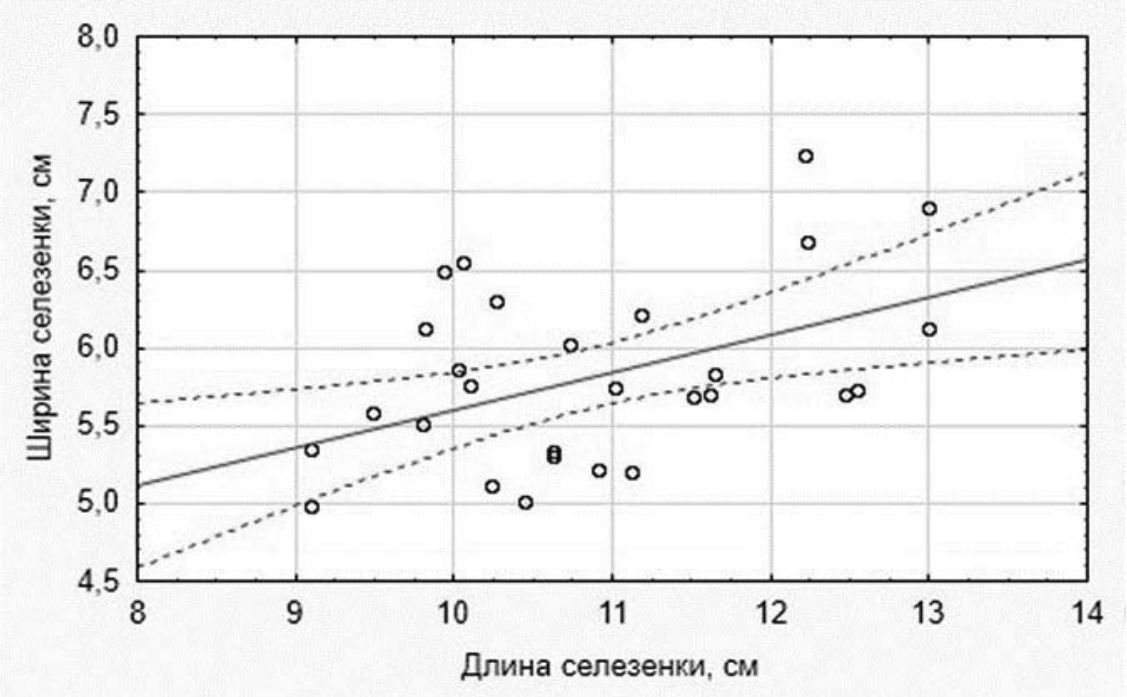

Рис. 4. График зависимости между длиной и шириной селезенки по данным ультразвукового исследования

телей нормальному закону или было отлично от него, использовались параметрические (коэффициент корреляции Пирсона) или непараметрические критерии (коэффициент корреляции Спирмена).

У всех исследуемых была установлена средняя по силе положительная линейная корреляционная связь между длиной и шириной селезенки ( ${ }^{*}=0,49, p<0,01$, где $r^{*}-$ коэффициент корреляции Пирсона, p - уровень значимости здесь и далее по тексту) (рис.1.).

Уравнение регрессии, описывающее данную корреляционную связь, имеет следующий вид:

$$
y=3,1521+0,23966 \times x,
$$

где y - ширина селезенки, $\mathrm{x}$ - длина селезенки.

У лиц эндо-мезоморфного типа телосложения была установлена средняя положительная линейная корреляционная связь между ростом и длиной селезенки ( $\left.\mathrm{r}^{*}=0,44, \mathrm{p}<0,01\right)$ (рис.2.).

Уравнение регрессии, описывающее данную корреляционную связь, имеет вид:

длина селезенки $=-4,620+, 09398 \times$ Рост,

где длина селезенки у -длина селезенки, х рост.

Также была установлена средняя положительная линейная корреляционная связь между весом и длиной селезенки $\left(\mathrm{r}^{*}=0,45, \mathrm{p}<0,01\right)$ (рис.3.).

Уравнение регрессии, описывающее данную корреляционную связь, имеет вид: длина селезенки =6,5241+,07007 $\times$ Вес где у -длина селезенки, х - вес.
Средняя положительная линейная корреляционная связь была установлена у лиц эндомезоморфного типа телосложения между длиной селезенки и ее шириной $\left(\mathrm{r}^{*}=0,47, \mathrm{p}<0,01\right)$ (рис. 4.).

Уравнение регрессии, описывающее данную корреляционную связь, имеет вид:

$$
\text { ширина селезенки }=3,1947+
$$$$
\text { 0,24049 × длина селезенки, }
$$

где у - ширина селезенки, $\mathrm{x}$ - длина селезенки.

Таким образом, у всех исследуемых была установлена средняя по силе положительная линейная корреляционная связь между длиной и шириной селезенки. У лиц эндо-мезоморфного типа телосложения были установлены средние положительные линейные корреляционные связи между ростом и длиной селезенки, весом и длиной органа, а также между длиной селезенки и ее шириной.

\section{В Ы В 0 д Ы}

Получены средние значения морфометрических параметров селезенки, которые могут быть использованы в качестве ультразвукового эталона нормы. Установлена взаимосвязь между количественными параметрами и антропометрическими показателями у лиц женского пола первого периода зрелого возраста Донецкого региона. 


\title{
В.А. Васильев, Р.В. Басий, А.И. Кулиш, О.А. Бешуля
}

ГОО ВПО «Донецкий национальный медицинский университет имени М. Горького», Донецк

\section{ВЗАИМОСВЯЗЬ МОРФОМЕТРИЧЕСКИХ ПАРАМЕТРОВ СЕЛЕЗЕНКИ И АНТРОПОМЕТРИЧЕСКИХ ПОКАЗАТЕЛЕЙ ЛИЦ ЖЕНСКОГО ПОЛА ПЕРВОГО ПЕРИОДА ЗРЕЛОГО ВОЗРАСТА В ДОНЕЦКОМ РЕГИОНЕ}

Вступление. Селезенка является индикатором большого числа патологических состояний. Наиболее информативным для оценки размеров селезенки и ее структуры является метод ультразвукового исследования. Корректную оценку морфометрических параметров селезенки, полученных при ультразвуковом исследовании, необходимо осуществлять с учетом половозрастных, антропометрических и соматотипологических особенностей исследуемого.

Цель работы. Определить морфометрический эталон нормы селезенки, установить взаимосвязь количественных параметров органа и антропометрических показателей практически здоровых лиц женского пола первого периода зрелого возраста в Донецком регионе.

Материал и методы. Объект исследования: 60 условно здоровых женщин в возрасте от 21 до 35 лет. На первом этапе работы проводилось ультразвуковое исследование селезенки. Определялись следующие морфометрические параметры: длина, ширина и толщина селезенки, а также рассчитывался объем селезенки. Далее проводилась антропометрия обследуемых с целью последующего определения соматотипа по методике Б.Х. Хит, Д.Л. Картера. Полученные результаты обрабатывались в пакете прикладных программ Statistica 10.

Результаты и обсуждение. Результаты соматотипирования обследуемых позволяют утверждать, что среди лиц женского пола первого периода зрелого возраста Донецкого региона преобладают эндомезоморфный и мезо-эндоморфный соматотипы.
Среднее значение показателя роста всех обследу-

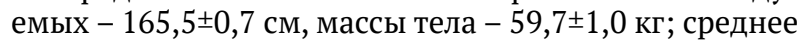
значение длины селезенки, полученное при ультразвуковом исследовании, составило $10,9 \pm 0,1$ см, ши-

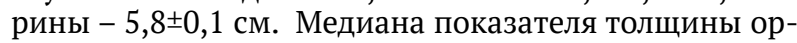
гана оказалась равна $4,7 \pm 0,1 \mathrm{~cm}$, объема селезенки $154,8 \pm 5,4 \mathrm{~cm}^{3}$.

На следующем этапе работы было определено наличие линейной корреляционной связи между величинами изучаемых показателей как независимо от соматотипа, так и у лиц наиболее часто встречающегося - эндо-мезоморфного соматотипа.

У всех исследуемых была установлена средняя по силе положительная линейная корреляционная связь между длиной и шириной селезенки. У лиц эндомезоморфного типа телосложения были установлены средние положительные линейные корреляционные связи между ростом и длиной селезенки, весом и длиной органа, а также между длиной селезенки и ее шириной.

Выводы. Получены средние значения морфометрических параметров селезенки, которые могут быть использованы в качестве ультразвукового эталона нормы. Установлена взаимосвязь между количественными параметрами селезенки и антропометрическими показателями у лиц женского пола первого периода зрелого возраста в Донецком регионе.

Ключевые слова: селезенка, ультразвуковое исследование, длина селезенки, ширина селезенки, толщина селезенки, объем селезенки, соматотипирование.

\section{V.A. Vasylyev, R.V. Basiy, H.I. Kulish, O.O. Beshulia}

\author{
SEI HPE «M. Gorky Donetsk National Medical University», Donetsk
}

\section{INTERRELATION BETWEEN MORPHOMETRIC PARAMETERS OF THE SPLEEN AND ANTHROPOMETRIC PARAMETERS OF WOMEN OF THE FIRST PERIOD OF ADULTHOOD OF THE DONETSK REGION}

Introduction. The spleen is an indicator of a large number of pathological conditions. The most informative method for evaluating the size of the spleen and its structure is ultrasound. Correct assessment of the morphometric parameters of the spleen obtained during ultrasound examination should be carried out taking into account the gender, age, anthropometric and somatotypological characteristics of the subject.

Purpose of work. To determine the morphometric standard of the spleen norm, to establish the relationship between the quantitative parameters of the organ and anthropometric indicators of practically healthy female individuals of the first period of adulthood in the Donetsk region.

Material and methods. Object of research: 60 conditionally healthy women aged 21 to 35 years. At the first stage of the work, an ultrasound examination of the spleen was performed. The following morphometric parameters were determined: the length, width and thickness of the spleen, and the volume of the spleen was cal- culated. Next, the anthropometry of the subjects was performed in order to determine the somatotype using the method of B. H. Heath and D. L. Carter. The results were processed in the Statistica 10 application software package.

Results and discussion. The results of somatotyping of the subjects suggest that endo-mesomorphic and meso-endomorphic somatotypes predominate among women of the first period of adulthood in the Donetsk region.

The average value of the growth index of all subjects was $165.5 \pm 0.7 \mathrm{~cm}$, body weight $-59.7 \pm 1.0 \mathrm{~kg}$; the average value of the spleen length obtained by ultrasound was $10.9 \pm 0.1 \mathrm{~cm}$, width $-5.8 \pm 0.1 \mathrm{~cm}$. The median organ thickness was $4.7 \pm 0.1 \mathrm{~cm}$, and the spleen volume was $154.8 \pm 5.4 \mathrm{~cm} 3$.

At the next stage of the work, the presence of a linear correlation between the values of the studied indicators was determined both independently of the somatotype and in individuals with the most common endo mesomorphic somatotype. 
All subjects had an average positive linear correlation between the length and width of the spleen. In individuals of endo-mesomorphic body type, average positive linear correlations were established between the height and length of the spleen, weight and length of the organ, as well as between the length of the spleen and its width.

Conclusions. The average values of morphometric parameters of the spleen can ould be used as an ultra- sound standard of norm. Were established the relationship between quantitative parameters of the spleen and anthropometric parameters of women of the first period of adulthood in the Donetsk region.

Key words: spleen, ultrasonography, spleen length, splenic width, thickness of the spleen, the volume of the spleen, somatotyping.

\section{ЛИТЕРАТУРА}

1. Pozo A, Godfrey E, Bowles K. Splenomegaly: Investigation, diagnosis and management. Blood Rev. 2009; 23(3):105111. doi:10.1016/j.blre.2008.10.001

2. Белік Н.В., Брухнова Л.С. Актуальність визначення індивідуальних нормативних ехометричних показників внутрішніх органів черевної порожнини. Biomedical and Biosocial Anthropology. 2006; 6: 25-29.

3. Гунас I.В., Белік Н.В., Прокопенко С.В. Моделювання індивідуальних ехопараметрів печінки, підшлунково і залози, селезінки і жовчного міхура методом покрокового регресійного аналіза у здорових міських підлітків Поділля. Світ медицини та біології. 2006; 2: 12-15.

4. Бунак В.В. Антропометрия. М.; Учмедгиз; 1941. 367.

5. Carter J.E.L. The Heath-Carter anthropometric somatotype: instruction manual. 2002.

6. Митьков В. В. Практическое руководство по ультразвуковой диагностике. Общая ультразвковая диагностика. М.: Издательский дом Видар; 2005. 720.

7. Çeliktas M, Özandaç S, Göker P, Bozkir M. Sonographic Determination of Normal Spleen Size in Turkish Adults. International Journal of Morphology. 2015; 33(4):1401-1405. doi: $10.4067 / \mathrm{s} 0717-95022015000400035$

\section{REFERENCES}

1. Pozo A, Godfrey E, Bowles K. Splenomegaly: Investigation, diagnosis and management. Blood Rev. 2009; 23(3):105111. doi:10.1016/j.blre.2008.10.001

2. Belik N.V., Bruhnova L.S. Aktual'nist' viznachennja individual'nih normativnih ehometrichnih pokaznikiv vnutrishnih organiv cherevnoï porozhnini. [Relevance of determining individual standard echometric parameters of internal organs of the abdominal cavity]. Biomedical and Biososial Anthropology. 2006; 6: 25-29 (in Ukrainian).

3. Gunas I.V., Belik N.V., Prokopenko S.V. Modeljuvannja individual'nih ehoparametriv pechinki, pidshlunkovo $i$ zalozi, selezinki i zhovchnogo mihura metodom pokrokovogo regresijnogo analiza u zdorovih mis'kih pidlitkiv Podillja. [Modeling of individual echoparameters of the liver, pancreas, spleen and gallbladder by step-by-step regression analysis in healthy urban adolescents of Podillia]. Svit medicini ta biologii. 2006; 2: 12-15 (in Ukrainian).

4. Bunak V.V. Antropometriya. [Anthropometry]. Moscow: Uchmedgiz; 1941. 367 (in Russian).

5. Carter J.E.L. The Heath-Carter anthropometric somatotype: instruction manual. 2002.

6. Mit'kov V. V. Prakticheskoe rukovodstvo po ul'trazvukovoi diagnostike. Obshchaya ul'trazvkovaya diagnostika. [Practical guide to ultrasound diagnostics. General ultrasound diagnostics]. Moscow: Izdatel'skii dom Vidar; 2005. 720. (in Russian).

7. Çeliktas M, Özandaç S, Göker P, Bozkir M. Sonographic Determination of Normal Spleen Size in Turkish Adults. International Journal of Morphology. 2015; 33(4):1401-1405. doi:10.4067/s0717-95022015000400035 